\title{
Phytochemical Analysis of Extracts from the Atlantic Forest Wood Species
}

\author{
Hanna Lisa Leffever Ribeiro dos Santos ${ }^{1}$ (D), Natalia Souza ${ }^{1}$, \\ Nathalia Rodrigues Macedo ${ }^{1}$, João Paulo da Silva Ramos ${ }^{1}$, \\ Ananias Francisco Dias Júnior ${ }^{2}$ (D), Alexandre Nascimento ${ }^{1}$ \\ ${ }^{1}$ Universidade Federal Rural do Rio de Janeiro - UFRRJ, Seropédica/RJ, Brasil \\ ${ }^{2}$ Universidade Federal do Espírito Santo - UFES, Jerônimo Monteiro/ES, Brasil
}

\begin{abstract}
The extractives are responsible for some characteristics of wood, such as color, smell, natural resistance to rot, taste, and abrasive properties. In addition, its content and composition vary between wood species. The objective of this work was to present a phytochemical analysis of wood extractives of native species from the Atlantic Forest, aiming at the characterization of some classes of secondary metabolites. Phytochemical tests for the detection of classes of metabolites present in Croton Urucurana Baill, Pelthoforum dubium (Spreng.) Taub., Jacaranda cuspidifolia Mart., and Hymenaea courbaril L. were carried out with crude wood, hydrophilic extract (methanol), and lipophilic extract (cyclohexane). Phytochemical analysis detected the presence of alkaloids, phenolic compounds, and triterpenoids in all the hydrophilic extracts of the species studied. Saponins were only detected in P. dubium and J. cuspidifolia. Phytochemical analysis permitted the identification of several metabolites, suggesting possible pharmacological actions of the species studied.
\end{abstract}

Keywords: chemical composition, wood extractives, secondary wood metabolites. 


\section{INTRODUCTION}

Wood is composed of cellulose, hemicelluloses, and lignin, in addition to a smaller number of extractives and inorganic materials (Valette et al., 2017). The extractives play an important role in the use of wood, influencing its physical, aesthetic, and resistance properties to insects and fungi due to its phenolic nature (Fu et al., 2018).

Extractives are chemicals in wood that can be extracted using different solvents, for example: water, neutral organic solvents, or steam volatilization. The extractives are present in the bark, leaves and needles, flowers, fruits, and seeds, and almost always, the quantities in these parts of the tree are proportionally larger than in the inner parts of the tree (Todaro et al., 2017; Fu et al., 2018). The extractives are often responsible for certain characteristics of wood, such as: color, smell, natural resistance to rot, taste, and abrasive properties. The content and composition of extractives vary among wood species (Verpoorte et al., 1999; Valette et al., 2017).

As for chemical composition, the extractives are generally composed of terpenes, essential oils, resins, phenols, tannins, fatty acids, and dyes (Wink, 2013). Several authors have suggested the importance of chemical and pharmacological studies in tropical plants due to the intense production of secondary metabolites in species from these ecosystems (Gottlieb, 1981). The investigation of the extracts obtained from both the wood and the bark, seeds, and leaves of the plants can lead to the characterization and isolation of metabolites with biological activities and new materials for the cosmetics, food, timber, and other applications. Brazil has scientific knowledge about a percentage, albeit low, of plants intended for medicinal use, and Brazilian companies have the necessary training to generate technological processes (Klein et al., 2009).

The first stage of the chemical studies with plants involves the phytochemical analysis of the extracts for the presence of the most relevant groups or classes of metabolites, which includes isolation, structural elucidation, and identification (Barbosa et al., 2006). Chemical substances or compounds that occur quite frequently in woody plants are phenols, flavonoids and derivatives, terpenes, alkaloids, cyanogenic compounds, quinones, and others (Wink, 2013).
Brazil has six large biomes, which together have one of the largest biodiversity on the planet, sheltering 55 thousand cataloged species and 4 thousand species of plants that are used for medicinal purposes. Among these biomes is the Atlantic Forest, which is the second largest tropical rainforest in Brazil. It is one of the most important and richest, biodiverse biomes on the planet, where thousands of plant species live, some of which are endemic. However, it is one of the most threatened, and many plant species are in extinction due to deforestation (Ribeiro et al., 2009).

The study of the native species of this biome and its medicinal potential is essential. Among the known species that have medicinal properties are Piptadenia gonoacantha (Mart.) J. F. Macbr (Pau-jacaré), in which phytochemical studies found several classes of chemical components such as aspefenamato, terpenoids, and flavonoids (Carvalho et al., 2010). Flavonoids are responsible for anti-inflammatory and anti-allergic effects. Among the medicinal potentials of the species, apigenin, which acts in the fight against cancer, is also outstanding. Myroxylon peruiferum Linnaeus (Cabreúva), from which Peruvian balsam is extracted, is used in folk medicine as an analgesic for urinary and respiratory tract infections, diabetes, and against the gram-negative Helicobacter pylori microbacterium, in addition to being used by cosmetics and perfumery (Esmaeili et al., 2012; Sartori et al., 2015).

Considering the importance of better understanding for new applications of extractives present in wood, this work had the objective of performing a phytochemical analysis of wood extractives of native species from the Atlantic Forest, aiming at the characterization of possible classes of secondary metabolites.

\section{MATERIAL AND METHODS}

\subsection{Origin and sampling of arboreal individuals}

The wood samples were obtained from tree individuals collected at the Experimental Station of Forest Sciences of Anhembi, SP, belonging to the University of São Paulo (LCF/ESALQ/USP). Wood samples were collected from four(4) 14-years-old individuais from each of the respective species: Croton urucurana Baill (Sangra D'água), Pelthoforum dubium (Canafístula), Jacaranda cuspidifolia (Jacarandá-de-minas), and 


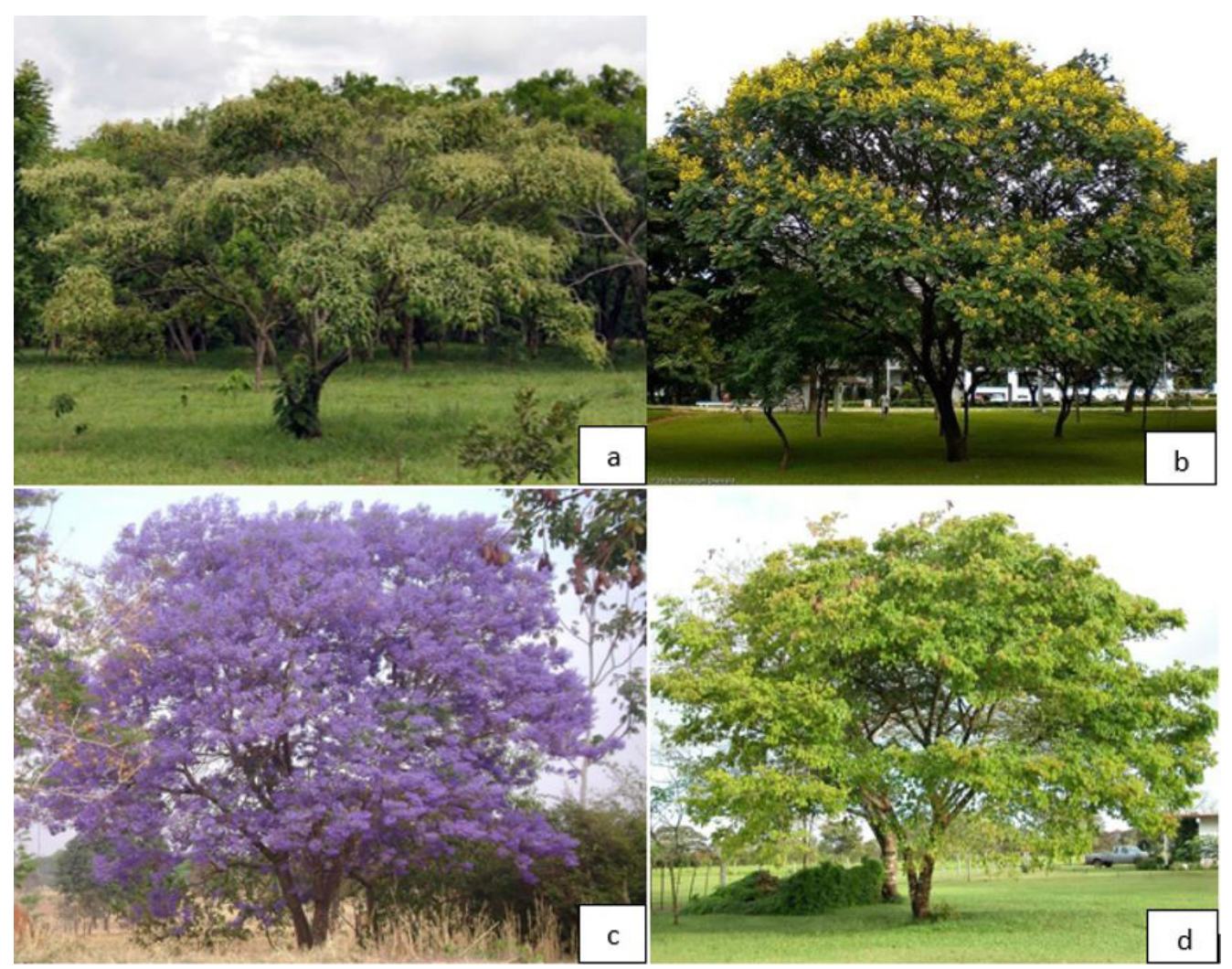

Figure 1. (a) Specimen of Croton urucurana Baill; (b) Specimen of Pelthoforum dubium; (c) Specimen of Jacaranda cuspidifolia; (d) Specimen of Hymenaea courbaril.

Hymenaea courbaril (Jatobá) (Figure 1). Samples were taken from the base and from four different positions $(25,50,75$, and $100 \%)$ of the total height of the trunk. These samples were pulverized and homogenized to form a compound sample (by species) for the subsequent analyses.

\subsection{Preparation of organic extracts}

The soxhlet apparatus was used for the extraction, using $6.00 \mathrm{~g}$ of wood sample. The material was conditioned in a cartridge made of filter paper and placed inside the extraction tube. The solvent was placed in a $1000 \mathrm{~mL}$ flask. The extraction time for each solvent (cyclohexane, ethyl acetate, and methanol) was 48 hours uninterrupted. Right after this period, the flasks containing the soluble material were concentrated in a rotary evaporator, achieving the concentration of the soluble material (evaporation of the solvent). The concentrates were transferred to a vessel until complete evaporation of the solvent at room temperature (Abreu et al., 2006).

\subsection{Phytochemical analysis}

The phytochemical tests for identification of the components present in the wood in this study were carried out following the methodologies proposed by Costa (1995), Matos (1997), and Rodrigues et al. (2010). The analyses were performed with wood, hydrophilic extract (methanol), and lipophilic extract (cyclohexane). All tests were performed in duplicate.

From the wood, tests were carried out to detect cyanogenic heterosides and alkaloids (Reaction with Dragendorff and Mayer). The hydrophilic extract was tested for phenols and tannins (reaction with ferric chloride), anthocyanins, anthocyanins, and flavonoids ( $\mathrm{pH}$ variation test with sodium hydroxide and hydrochloric acid) (Table 1), leucoantocyanidins, catechins and flavones ( $\mathrm{pH}$ variation test and heating with sodium hydroxide and hydrochloric acid) (Table 2), flavanones, flavanones and xanthones (Shinoda test), steroids and triterpenoids (Lierbemann-Burchard test), 
Table 1. Reactions to identify anthocyanins, anthocyanidins, and flavonols.

\begin{tabular}{lccc}
\multicolumn{1}{c}{ Constituents } & pH 3 & pH 8.5 & pH $\mathbf{1 1}$ \\
Anthocyanins and Anthocyanidins & Red & Lilac & Blue \\
Flavones, Flavonols, and Xanthones & - & - & Purple \\
Chalcones and Auronas & Red & - & Red \\
Flavanonols & - & - & Purple \\
\hline
\end{tabular}

Table 2. Reactions to identify leucoanthocyanidins, catechins, and flavones.

\begin{tabular}{lcc}
\multicolumn{1}{c}{ Constituents } & pH 3 & pH 11 \\
\hline Leucoantocianidines & Red & - \\
Catechins & Yellowish brown & - \\
\hline Flavanones & - & Red-Orange \\
\hline
\end{tabular}

saponins (foam test), resins (turbidity test of the extract), and alkaloids (reaction with Dragendorff and Mayer).

The lipophilic extract was tested for alkaloids, phenolic constituents, steroids, and triterpenoids using anthraquinones (reaction with $\mathrm{NH}_{4} \mathrm{OH}$ ) and coumarins (fluorescence test under UV light), using the reactions mentioned above. The results were evaluated qualitatively through the results of colorimetric reactions, foaming, precipitation, and fluorescence appearance.

\section{RESULTS AND DISCUSSION}

The cyanogenic heterosides were not detected in the extractives of the species studied (Table 3 ). Plants that have these compounds become toxic to humans because the compound can be converted into its byproducts (glucose, cyanide, and acetone) by the enzymatic action produced by the intestinal flora. The cyanide released in the reaction inhibits the essential cytochrome oxidase enzyme in the process of cellular respiration (Câmara et al., 2014).

It can be observed that alkaloids, phenolic compounds, and triterpenoids were found in all the hydrophilic extracts of the species studied (Table 4).

The alkaloids are very active in plants and represent the class of secondary metabolites with the greatest structural diversity. This class is known for the presence of substances that have a marked effect on the nervous system, many of them being used as poisons or hallucinogens (Kabera et al., 2014). In some cases, alkaloids work in plants as protective agents against pests and diseases. They also present a wide range of anesthetic, analgesic, antipyretic, anticholinergic, antitussive, and central nervous system stimulant properties, among others (Barbosa-Filho et al., 2006). Triterpenes are compounds of great interest in traditional medicine (Silva \& Lima, 2016). Terpenoids are antibacterial, antifungal, antiviral, and anti-protozoal (Mayer et al., 2017).

Among the phenolic compounds, the presence of tannins in Pelthoforum dubium and Jacaranda cuspidifolia was identified (Table 4). The tannins are composed of a complex polyphenolic structure and occur in most bark and in some woods; however, they are in sufficient quantity for economic exploitation in only a few species. They present higher production in woody plants of the group of Angiosperms and are responsible for the resistance of plants against the attack of pathogenic microorganisms (Cornwell et al., 2009). The presence of tannins is related to the medicinal action for gastrointestinal diseases, since its astringent characteristic is effective in the treatment of diarrhea (Almeida et al., 1995). Tannins also present antimicrobial, antiviral, antifungal, antiseptic, anti-infective, anti-bacterial, and antiprotozoal properties, as well as influencing tissue repair, enzymatic and protein regulation, phagocytic cell stimulation, and tumor action (Monteiro et al., 2005; Bessa et al., 2013).

The test for flavones, flavonols, and xanthones was positive for all species (Table 4). In the tests for identification of flavanonols, the presence of these compounds was not observed. Flavonols, flavanones, flavanonols, and xanthones were positive for all species except Jacaranda Cuspidifolia. For this species, only the presence of flavones was detected (Table 4).

Flavonoids are widely distributed throughout the plant kingdom and are notable for their diverse biological actions, including the ability to act on inflammation and on the immune system (Coutinho et al., 2009). 
Table 3. Results of phytochemical analysis in wood of the species studied.

\begin{tabular}{lcccc}
\multicolumn{1}{c}{ Constituents } & Croton urucrana & $\begin{array}{c}\text { Pelthoforum } \\
\text { dubium }\end{array}$ & $\begin{array}{c}\text { Jacaranda } \\
\text { cuspidifolia }\end{array}$ & $\begin{array}{c}\text { Hymenaea } \\
\text { courbaril }\end{array}$ \\
\hline Cyanogenic Heterosides & ND & ND & ND & ND \\
Alkaloids & D & D & D & ND \\
\hline
\end{tabular}

$\mathrm{D}=$ compound detected $\mathrm{ND}=$ compound not detected.

Table 4. Phytochemical analysis in hydrophilic extract of the species studied.

\begin{tabular}{|c|c|c|c|c|}
\hline Constituents & Croton urucrana & $\begin{array}{l}\text { Pelthoforum } \\
\text { dubium }\end{array}$ & $\begin{array}{l}\text { Jacaranda } \\
\text { cuspidifolia }\end{array}$ & $\begin{array}{c}\text { Hymenaea } \\
\text { courbaril }\end{array}$ \\
\hline Alkaloids & $\mathrm{D}$ & $\mathrm{D}$ & $\mathrm{D}$ & $\mathrm{D}$ \\
\hline Tannins & ND & $\mathrm{D}$ & $\mathrm{D}$ & ND \\
\hline Phenols & $\mathrm{D}$ & $\mathrm{D}$ & $\mathrm{D}$ & $\mathrm{D}$ \\
\hline Anthocyanins and Anthocyanidins & ND & ND & ND & ND \\
\hline Flavones, Flavonols, Xanthones & $\mathrm{D}$ & $\mathrm{D}$ & $\mathrm{D}$ & $\mathrm{D}$ \\
\hline Chalcones, Auronas & ND & ND & ND & ND \\
\hline Flavanonols & ND & ND & ND & ND \\
\hline Leucoantocianidines & ND & ND & ND & ND \\
\hline Catechins & $\mathrm{D}$ & ND & $\mathrm{D}$ & $\mathrm{D}$ \\
\hline $\begin{array}{l}\text { Flavanones, Flavanones, Flavanones } \\
\text { and Xanthones }\end{array}$ & $\mathrm{D}$ & $\mathrm{D}$ & ND & $\mathrm{D}$ \\
\hline Steroids & ND & ND & ND & ND \\
\hline Triterpenoids & $\mathrm{D}$ & $\mathrm{D}$ & $\mathrm{D}$ & $\mathrm{D}$ \\
\hline Saponins & ND & $\mathrm{D}$ & $\mathrm{D}$ & ND \\
\hline Resins & ND & ND & ND & ND \\
\hline
\end{tabular}

$\mathrm{D}=$ compound detected; $\mathrm{ND}=$ compound not detected.

Several functions are attributed to flavonoids in plants, such as protection of plants against the incidence of ultraviolet rays and the visible spectrum, against herbivores, fungi, viruses, and bacteria, as well as serving to attract pollinating animals and acting as antioxidants, hormones, allelopathic agents, and inhibitors of enzymes (Kabera et al., 2014). Flavonoids also have antiulcerogenic, cytotoxic, antineoplastic, antihepatotoxic, antihypertensive, hypolipidemic, anti-inflammatory, and antiplatelet properties (Machado et al., 2008).

Only Pelthoforum dubium did not present catechin. In addition, the flavonoids of the flavanols class are considered intermediates, together with the leucoanthocyanidins, in the synthesis of condensed tannins (Neiva et al., 2003; Salminen \& Karonen, 2011). Catechins are potent antioxidants, free radical scavengers, metal chelators, and lipid peroxidation inhibitors (Schmitz et al., 2005).

Saponins are present in Pelthoforum dubium and Jacaranda cuspidifolia. They are characterized by their tensioactive properties and can form complexes with proteins and phospholipids of the cell membrane, determining their biological actions (Table 4). This property may alter the permeability of membranes, which may aid in the absorption of substances or destroy it, indicating a toxic characteristic (Piasecka et al., 2015). The hemolytic activity of saponins, which is part of the plant's protection system against predators (insects, viruses, fungi and bacteria), is linked to many of the antibacterial, antifungal, and spermicidal activities. In addition to these activities, saponins have activities against other microorganisms, such as viruses and nematodes (Soetan et al., 2014).

Although chalcones have not been detected in the studied species (Table 4), these compounds are of great importance in the metabolism of the plants that possess them, as they are intermediates in the formation of all the flavonoids. Chalcone can also be converted to aurone, another flavonoid compound that has not been found in any of the species (Costa, 1995).

Table 5 shows the constituents observed in the lipophilic extracts of the four species studied. It can be observed that there was no detected presence of 
Table 5. Phytochemical analysis in lipophilic extract of the species studied.

\begin{tabular}{lcccc} 
Constituents & Croton urucrana & $\begin{array}{c}\text { Pelthoforum } \\
\text { dubium }\end{array}$ & $\begin{array}{c}\text { Jacaranda } \\
\text { cuspidifolia }\end{array}$ & $\begin{array}{c}\text { Hymenaea } \\
\text { courbaril }\end{array}$ \\
\hline Alkaloids & ND & ND & D & D \\
\hline Tannins & ND & ND & ND & ND \\
\hline Phenols & D & ND & ND & ND \\
\hline Anthocyanins and Anthocyanidins & ND & ND & ND & ND \\
\hline Flavones, Flavonols, Xanthones & ND & ND & ND & ND \\
\hline Chalconas, Auronas & ND & ND & ND & ND \\
\hline Flavanonols & ND & ND & ND & ND \\
\hline Leucoantocianidines & ND & ND & ND & ND \\
\hline Catechins & ND & ND & ND & ND \\
\hline $\begin{array}{l}\text { Flavanones, Flavanones, Flavanones, } \\
\text { and Xanthones }\end{array}$ & ND & D & ND & ND \\
\hline Steroids & ND & D & ND & ND \\
\hline Triterpenoids & ND & ND & ND & ND \\
\hline Anthraquinones & ND & ND & ND & ND \\
\hline Cumarinas & ND & ND & ND & ND \\
\hline
\end{tabular}

$\mathrm{D}=$ compound detected $\mathrm{ND}=$ compound not detected .

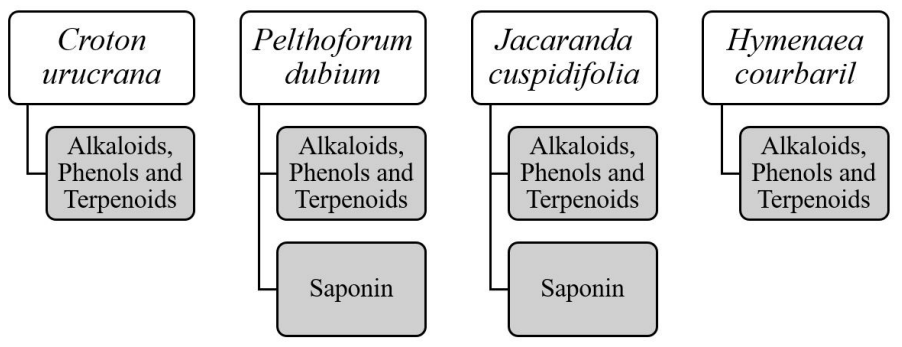

Figure 2. Summary of the classes of constituents present in the species studied.

secondary metabolic classes for most of the tests performed.

The presence of phenols in Croton urucrana was detected, confirming the previously obtained result for the hydrophilic extract. The same occurred for Jacaranda cuspidifolia and Hymenaea courbaril, in which the presence of alkaloids was detected.

In Pelthoforum dubium, the presence of steroids, which are part of one of the largest groups of secondary metabolites (terpenes), has been observed. There are references indicating that compounds of this class exhibit cytotoxic, antitumor, antiviral, antioxidant, and anti-inflammatory activity. Plant steroids are important anti-inflammatory agents and may have antiseptic and analgesic properties similar to aspirin (Araújo, 2014).

A very widespread class of substances not identified (Table 5) by the tests performed were coumarins. These have marked effects on plant physiology, affect photosynthesis and photophosphorylation, reduce glucose synthesis, and inhibit the initial steps of chlorophyll biosynthesis. Among the physiological effects, alteration in the normal plant growth and seed germination are included (Costa, 1995).

It can be verified that the classes of constituents present in Croton urucrana and Hymenaea courbaril were alkaloids, phenols, and terpenoids. Pelthoforum dubium and Jacaranda cuspidifolia presented saponin, in addition to those compounds (Figure 2).

The phenolic constituents are derived from secondary plant metabolism and may occur in the cell wall of plant tissues, functioning as a substrate for peroxidases and polyphenoloxidases (Silva et al., 2016). The occurrence of these constituents is generally associated with the herbivory responses (Heng-Moss et al., 2004), which comprise the polymerization of these compounds in the cell wall and are the fastest line of plant defense against lesions and infections (Matern \& Kneusel, 
1988). Slow-growing species occur in sites with limited resources for favorable development and low reutilization of plant matter through the process of senescence (Chapin, 1980). This fact is due to the predominant occurrence of lignins and tannins in plant tissues. Thus, such compounds at least guarantee sufficient protection in the development of plant tissues despite herbivore evolution, while being expensive to the individual's metabolism. This protection is characterized by greater rigidity, consequently, greater difficulty in eating, and the constitution of less palatable plant tissues. As a result, there is less demand for such plant resources by herbivores in the long term (Chapin, 1980; Osunkoya et al., 2008).

\section{CONCLUSIONS}

Phytochemical analysis detected the presence of alkaloids, phenolic compounds, and triterpenoids in all the hydrophilic extracts of the species studied. Saponins were only detected in P. dubium and J. cuspidifolia.

Some extractives are widely used commercially in the pharmaceutical and cosmetic industries in the form of creams, lotions, gels, and others. Despite these applications, many biochemical and molecular aspects of extractives are still poorly understood. This study may suggest possible pharmacological actions of the species studied, in addition to allowing for better identification of its active principles.

\section{ACKNOWLEDGEMENTS}

I would like to thank God for guiding me here and putting good people on my path, who helped me complete this work.

\section{SUBMISSION STATUS}

Received: 24 sept., 2018

Accepted: 4 dec., 2018

\section{CORRESPONDENCE TO}

\section{Hanna Lisa Leffever Ribeiro dos Santos}

Universidade Federal Rural do Rio de Janeiro

- UFRRJ, Rodovia BR 465, Km 07, s/n, CEP 23890-000, Seropédica, RJ, Brasil

e-mail: hannasantos@uol.com.br

\section{REFERENCES}

Abreu HS, Carvalho AM, Monteiro MBO, Pereira RPW, Silva HR, Souza KCA et al. Métodos de análise em química da madeira. Seropédica: Instituto de Florestas; 2006.

Almeida CE, Karnikowski MGO, Foleto R, Baldisserotto B. Analysis of antidiarrhoeic effect of plants used in popular medicine. Revista de Saúde Pública 1995; 29(6): 428-433. http://dx.doi.org/10.1590/S0034-89101995000600002. PMid:8734966.

Araújo LLN. Prospecção fitoquímica da espécie Justicia pectoralis Jacq. var. stenophylla Leonard pertencente à família Acanthaceae. Revista Eletrônica de Ciências Humanas, Saúde e Tecnologia 2014; 6(2): 4-14.

Barbosa AP, Palmeira RCF, Nascimento CS, Feitoza DS, Cunha MSC. Leguminosas Florestais da Amazônia Central. I. Prospecção das classes de compostos presentes na casca de espécies arbóreas. Revista Fitos 2006; 1(3): 47-57.

Barbosa-Filho JM, Piuvezam MR, Moura MD, Silva MS, Lima KVB, Cunha EVL et al. Anti-inflammatory activity of alkaloids: a twenty-century review. Revista Brasileira de Farmacognosia 2006; 16(1): 109-139. http://dx.doi.org/10.1590/ S0102-695X2006000100020.

Bessa NGF, Borges JCM, Beserra FP, Carvalho RHA, Pereira $\mathrm{MAB}$, Fagundes R et al. Prospecção fitoquímica preliminar de plantas nativas do cerrado de uso popular medicinal pela comunidade rural do assentamento vale verde - Tocantins. Revista Brasileira de Plantas Medicinais 2013; 15(4): 692707. http://dx.doi.org/10.1590/S1516-05722013000500010.

Câmara ACL, Dalcin L, Soto-Blanco B. Patogênese, sinais clínicos e epidemiologia das intoxicações por plantas cianogênicas no nordeste brasileiro Pathogenesis, clinical signs and epidemiology of the poisoning by cyanogenic plants in the Brazilian northwest. Semina. Ciências Agrárias, Londrina 2014; 35(4): 1961-1972. http://dx.doi.org/10.5433/16790359.2014v35n4p1961.

Carvalho MG, Cardozo MAR, Catunda FEA Jr, Carvalho AG. Chemical constituents of Piptadenia gonoacantha (Mart.) J.F. Macbr (pau jacaré). Anais da Academia Brasileira de Ciências 2010; 82(3): 561-567. http://dx.doi.org/10.1590/ S0001-37652010000300003. PMid:21562684.

Chapin FS 3rd. The mineral nutrition of wild plants. Annual Review of Ecology and Systematics 1980; 11(1): 233-260. http://dx.doi.org/10.1146/annurev.es.11.110180.001313.

Cornwell WK, Cornelissen JH, Allison SD, Bauhus J, Eggleton $\mathrm{P}$, Preston $\mathrm{CM}$ et al. Plant traits and wood fates across the globe: rotted, burned, or consumed? Global Change Biology 2009; 15(10): 2431-2449. http://dx.doi.org/10.1111/j.13652486.2009.01916.x.

Costa ASV. Identificação de substâncias secundárias presentes em leguminosas utilizadas como adubo verde. Ceres 1995; 42(244): 585-598.

Coutinho MAS, Muzitano MF, Costa SS. Flavonoides: potenciais agentes terapêuticos para o processo inflamatório. 
Revista Virtual de Química 2009; 1(3): 241-256. http://dx.doi. org/10.5935/1984-6835.20090024.

Esmaeili D, Mobarez AM, Tohidpour A. Anti-helicobacter pylori activities of shoya powder and essential oils of Thymus vulgaris and Eucalyptus globulus. The Open Microbiology Journal 2012; 6(1): 65-69. http://dx.doi.org/10.2174/18742 85801206010065. PMid:22927892.

Fu T, Elie N, Brunelle A. Radial distribution of wood extractives in European larch Larix decidua by TOF-SIMS imaging. Phytochemistry 2018; 150: 31-39. http://dx.doi. org/10.1016/j.phytochem.2018.02.017. PMid:29533839.

Gottlieb OR. New and underutilized plants in the americas: solution to problems of invetory through systematics. Interciencia 1981; 6(1): 22-29.

Heng-Moss T, Sarath G, Baxendale F, Novak D, Bose S, Ni $\mathrm{X}$ et al. Characterization of oxidative enzyme changes in buffalograsses challenged by Blissus occiduus. Journal of Economic Entomology 2004; 97(3): 1086-1095. http://dx.doi. org/10.1603/0022-0493(2004)097[1086:COOECI]2.0.CO;2. PMid:15279295.

Kabera JN, Semana E, Mussa AR, He X. Plant secondary metabolites: biosynthesis, classification, function and pharmacological properties. The Journal of Pharmacy and Pharmacology 2014; 2: 377-392.

Klein T, Longhini R, Bruschi ML, Mello JCP. Fitoterápicos: um mercado promissor. Revista de Ciências Farmacêuticas Básica e Aplicada 2009; 30(3): 241-248.

Machado H, Nagem TJ, Peters VM, Fonseca CS, Oliveira TT. Flavonóides e seu potencial terapêutico. Boletim do Centro de Biologia da Reprodução 2008; 27(1-2): 33-39.

Matern U, Kneusel R. Phenolic compounds in plant disease resistance. Phytoparasitica 1988; 16(2): 153-170. http://dx.doi. org/10.1007/BF02980469.

Matos FJA. Introdução à fitoquímica experimental. Fortaleza: EUFC; 1997.

Mayer A, Rodríguez AD, Taglialatela-Scafati O, Fusetani N. Marine pharmacology in 2012-2013: marine compounds with antibacterial, antidiabetic, antifungal, anti-inflammatory, antiprotozoal, antituberculosis, and antiviral activities; affecting the immune and nervous systems, and other miscellaneous mechanisms of action. Marine Drugs 2017; 15(9): 273. http:// dx.doi.org/10.3390/md15090273. PMid:28850074.

Monteiro JM, Albuquerque UP, Araujo EL. Tannis: from chemistry to ecology. Química Nova 2005; 28(5): 892-896. http://dx.doi.org/10.1590/S0100-40422005000500029.

Neiva TJC, Machado MJ, Hoehn M, Hermes EM, Vituri C, Ferreira JS et al. Efeito das catequinas (catequina e epicatequina) na agregação plaquetária. Revista Brasileira de Hematologia e Hemoterapia 2003; 25(4): 207-212.

Osunkoya OO, Daud SD, Wimmer FL. Longevity, lignin content and construction cost of the assimilatory organs of nepenthes species. Annals of Botany 2008; 102(5): 845-853. http://dx.doi.org/10.1093/aob/mcn162. PMid:18757449.
Piasecka A, Jedrzejczak-Rey N, Bednarek P. Secondary metabolites in plant innate immunity: conserved function of divergent chemicals. The New Phytologist 2015; 206(3): 948 964. http://dx.doi.org/10.1111/nph.13325. PMid:25659829.

Ribeiro MC, Metzger JP, Martensen AC, Ponzoni FJ, Hirota MM. The Brazilian Atlantic Forest: how much is left, and how is the remaining forest distributed? Implications for conservation. Biological Conservation 2009; 142(6): 11411153. http://dx.doi.org/10.1016/j.biocon.2009.02.021.

Rodrigues KAF, Dias CN, Florência JC, Vilanova CM, Gonçalves JRS, Coutinho-Moares DFL. Prospecção fitoquímica e atividade moluscicida de folhas de Momordica charantia L. Cadernos de Pesquisa 2010; 17(2): 69-76.

Salminen JP, Karonen M. Chemical ecology of tannins and other phenolics: we need a change in approach. Functional Ecology 2011; 25(2):325-338. http://dx.doi.org/10.1111/j.13652435.2010.01826.x.

Sartori ÂLB, Lewis GP, Freitas Mansano V, Azevedo Tozzi AMG. A revision of the genus Myroxylon (Leguminosae: papilionoideae). Kew Bulletin 2015; 70(4): 48. http://dx.doi. org/10.1007/s12225-015-9604-7.

Schmitz W, Saito AY, Estevão D, Saridakis HOO. Chá verde e suas ações como quimioprotetor. Ciências Biológicas e da Saúde 2005; 26(2): 119-130. http://dx.doi.org/10.5433/16790367.2005v26n2p119.

Silva ACO, Lima RA. Identificação das classes de metabólitos secundários no extrato etanólico dos frutos e folhas de Eugenia uniflora L. Revista Eletrônica em Gestão, Educação e Tecnologia Ambiental 2016; 20(1): 381-388.

Silva MDS, Silva RPD, Souza AVLD, Xavier YPM, Oliveira ACD, Coqueiro DSO. Exogenous application of salicylic acid in yellow passion fruit for the control of fruit woodiness virus. Arquivos do Instituto Biológico 2016; 83: e0082015.

Soetan KO, Ajibade TO, Akinrinde AS. Saponins; a ubiquitous phytochemical: a review of its biochemical, physiological and pharmacological effects. Recent Prog. Med. Plants 2014; 43: 1-24.

Todaro L, Russo D, Cetera P, Milella L. Effects of thermovacuum treatment on secondary metabolite content and antioxidant activity of poplar (Populus nigra L.) wood extracts. Industrial Crops and Products 2017; 109: 384-390. http://dx.doi.org/10.1016/j.indcrop.2017.08.052.

Valette N, Perrot T, Sormani R, Gelhaye E, Morel-Rouhier M. Antifungal activities of wood extractives. Fungal Biology Reviews 2017; 31(3): 113-123. http://dx.doi.org/10.1016/j. fbr.2017.01.002.

Verpoorte R, Van der Heijden R, Ten Hoopen HJG, Memelink J. Metabolic engineering of plant secondary metabolite pathways for the production of fine chemicals. Biotechnology Letters 1999; 21(6): 467-479. http://dx.doi. org/10.1023/A:1005502632053.

Wink M. Evolution of secondary metabolites in legumes (Fabaceae). South African Journal of Botany 2013; 89: 164175. http://dx.doi.org/10.1016/j.sajb.2013.06.006. 